\title{
VII. Observations on the British trade with Turkey
}

\section{W. Eton Esq.}

To cite this article: W. Eton Esq. (1799) VII. Observations on the British trade with Turkey , Philosophical Magazine Series 1, 3:11, 262-278, DOI: 10.1080/14786449908676993

To link to this article: http://dx.doi.org/10.1080/14786449908676993

曲 Published online: 18 May 2009.

Submit your article to this journal 준

Џ Article views: 3

Q View related articles $₫$ 
days pour off whichever of thefe liquids you have employed, and fupply its place with warm water, which ought to be changed every three or four hours, until it come off perfectly clear. When the matter with which the prints are dirtied is of a refinous nature, which fometimes happens, dip them in a little alcohol: afterwards fuffer all the moifture to drain off, and cover the prints with the liquor of the oxygenated muriatic acid made by minium. Place on the edges of the wax another pane of glafs, of the fame fize as that below, in order that you may not be too much incommoded by the fmell of the acid; and you will then plainly fee the yellowert prints refume their original whitenefs. One or two hours will be fufficient to produce the defred effect. Having then poured off the acid, wath the prints, feveral times, in pure water, and dry them in the fur.

VII. Obfervations on the Britif Trade with Turkey. From Eton's Survey of the Turkith Empire.

FormerLY the trade to Turkey was of confiderable importance to this country; but of late years it had been languifhing, and at laft dwindled into a fate of infignificancy, when the prefent war entirely put a ftop to all communication with the ports of the Levant.

As this trade will be again opened when a peace takes place, an inveftigation of the caufes of its decline, and the means to give it its ancient extenfion, may not, in the mean time, be unimportant to the government and to the merchants of this country.

The caufes of its gradual decline are, ift, The rivalfhip of other European nations; adly, The diminution of the confumption of our manufactures in Turkey, by the impoverifhed ftate of the country; $3 \mathrm{dly}$, Some branches of trade being got into other channels; and 4 thly, The monopoly of the Levant Company in London. 
With refpect to the rivalihip of other nations, that canfe will be confidered when I fpeak of the Levant Company. As to the impoverifhed ftate of 'Furkey, it muft affect the trade of other European nations as well as our own; if we are not, therefore, to expect to fee it again in that flourifhing ftate in which it was, when there were forty Englifh houfes of trade at Aleppo, (at prefent there is but one.) we may at leaft expect to have the fame proportion of it as we then had; and if we acquire only this; our trade to the Levant will fill be a national object. Some branches of trade are got into other channels; this regards principally certain imports from Turkey, and particularly of filk from Aleppo, whence formerly larger quantities of Perfian filk came, which is not now brought thither, but the Eaft India Company fupply our market cheaper and more abundantly. Confiderable quantities of cotton and drugs come from Holland and from Italy, which formerly came direct. This will alfo be accounted for in the next confideration, the monopoly of the Levant Company.

It is often neceffary, and where merchants undertake to open to the country a new branch of trade, and where the cxpence and rifk is great, it is juft, to grant them exclufive privileges, or monopolies, for a certain limited time, to prevent others from reaping the harveft they had fown, and to fecure their laudable induftry as far as polible from rifk; but when that rikk exifts no more, and when they have reaped their harveft over and over again, and-have had a full compenfation for their rifk, their induftry, and their expence, the country at large has a right to a participation of the trade. There may, indeed, fometimes exift circumftances of a pecu liar nature, which give them a claim to a longer indulgenes in their monopoly, particularly where that monopoly is no injurious, but, on the contrary, beneficial to the country in general, (and fuch is the cafe of the Eaft India Company;) but in a trade where the merchants have no common ftock, and can urge none of the above reafons in defence of their 
monopoly; where they cannot prove that any particular lofs would accrue to them by abolifhing it; where it has operated as a reftraint on the trade, confining it to narrow bounds, and giving a decided fuperiority to their rivals of other nations, to the almoft total exclufion of the products and manufactures of their country from that to which their privilege exclufively permits them to trade, ought in common fenfe fuch a monopoly to exift? The Levant Company is truly become the dog in the manger; it does not operate fo much to the profit of the company, as to the lofs of the country.

This monopoly is of a fingular nature: it has none of the advantages of a common ftock, in which many individuals rifk fmall fums, but which in the aggregate amount to a larger capital than any one merchant or fet of merchants poffers, or would choofe to rifk; a common ftock to which any one may contribute, and which thereby, ftrictly peaking, ceafes to be a monopoly: it is a privilege granted to certain perfons only to trade to Turkey, each with his own capital, and for his own particular account and rifk, without any affignable reafon why they hould be preferred to others his majefty's fubjects : it has all the difadvantages of other monopolies; it has not one of their advantages.

In fpeaking thus freely of the company, I folemnly declare that I have no private motive, no rancour againft any individual, and no inducement for writing on this fubject but the advantage of the country. The few members of the company with whom I am acquainted I perfonally refpect and highly efteem: on this fubject they mut differ with me; they are bound by oath to fupport the interefts of their body.

The trade of all other nations to Turkey is free, and they have experienced the advantage of being liberated from the fetters of exclufive privileges. Let every obftacle be removed in this country to an equally free commerce, and the fuperior induftry, ikill, and riches of our manufacturers, our 


\section{Britifs Trade with Turkey.}

traders, and our navigators, will again reftore to us our loft Turkey trade.

It may be faid, that at prefent the Levant Company is not a monopoly, as any one, by paying twenty pounds, may become a member of $i t$. When the trade was already ruined, it was imagined that this regulation was equivalent to laying the trade open, (a proof that government have thought it neceffary to abolifh the monopoly;) but the bye-laws of the company, and the power to enforce them, were permitted to exift, and thefe fo fetter the trade to new adventurers, that few have found their account in purfuing it, and the trade ftill remains a monopoly in favour of the old houfes.

It will be neceffary to pafs in review thefe bye-laws, which have operated fo injurioufly to the trade in general; and to thow how they, have gradually effected its total ruin, and the introduction of rivals, who have gotten poffeffion of what we have loft.

By one of the bye-laws, for inftance, it was enacted, that all merchandife brought from Turkey, and imported into England, thould be the produce of groods exported from England to Turkey. The following are the words of the bye-law:

"That upon entering goods received in England from Turkey or Egypt, every member thall in like manner fubfcribe the following affirmation; videlicet:

"I affirm, by the oath I have 'taken to the Levant Company, that the goods above mentioned are for account of myfelf, or others free of the faid company, or of fuch as now have their licence to trade, and are beyond the feas; and that the faid goods, nor any part of them, are not, to the beft of my knowledge, the produce of gold or filver, either in coin or bullion, fent into Turkey; but that the faid goods are purchafed by merchandife, or monies arifing or to arife from the fale of merchandife fent into Turkey or Egypt, from Europe, or from the Britifh fettlements in America, on account of freemen of the Levant Company, or fuch as have their licence to trade, and of which regular entries have been 
made with the company, or are purchafed by freight received in Turkey or Egypt, by thips navigated according to law; which freight is entirely the property of members of the company, or fuch as have their licence to trade."

And every merchant or factor in Turkey or Egypt is required to make a fimilar affidavit, on : exporting goods from Turkey for England; and to give, on oath, an exact aecount of every kind of tranfaction or bufinefs, direct and indirect; fo that all his affairs become known.

The object of this law is evidently to encourage the exportation of cloth; and when we had no rivals, it produced no bad effects; but it foon produced rivals, and it continued in force till they had nearly got poffeffion of the whole cloth trade. Such a law, indeed, was fufficient to ruin any trade. One houfe may-deal in exports, another in imports; one may combine its Italian with its Turkey trade; another may fend veffels for the carrying trade: but if every, individuat houfe be obliged to keep an exaet regifter on oath, and under a penalty of 20 per cent. called "a broke," of all its exports and imports, and to balance them exactly, how is fuch a trade to profper, where the profits are reduced by the rivalAlip of foreign nations? This bye-law at length, when it had produced the full effect of its ill tendency, was repealed; but the trade was not revived: fo difficult is it to turn back commerce from channels into which it has run.

It will be afked, then, what are the reftraints which now ite on the trade?

The fubjection to the control of the company; the neceffity of making entries with it of all their tranfactions on oath, and not being able to be concerned in anywife with others not free of the company, or foreigners; the power in the company, for the leaft violation of their rules, to inflict a penalty of 20 per cent.; the idea of reftraint, and the apprehenfion of violating a folemn oath, have made many determine to trade with Turkey through foreign and circuitous channels, without becoming free of the company: witners 
the very large quantities of cottons and drugs, \&c. which come from Holland and Italy, as the cuftom-houfe books prove. This was the cafe till our trade to Holland and the Mediterranean was ftopped by the war, and in that fame fituation we thall be when a peace takes place.

The drugs, \&c. which are imported from Italy, were carried thither. from Turkey; they had already given a profit to the Italian factor in Turkey; to the importer, and to the purchafer in Italy, who cleans, afforts, repacks, and often adulterates them; to the commiffioner, who purchafes them for his correfpondent in England; to which add charges, and intereft of money for fo long a difburfement, which the different people through whofe hands the merchandife has gone have all calculated, as well as their profits, double freights, and loading and unloading, \&c. \&cc.

Cottons are imported from Holland, becaufe the company cannot import themfelves enough for the confumption; and the reafon why they do not is, becaufe the old members, who are under no apprehenfions of the bye-laws, find other articles enow to employ their whole capital, and beyond that the trade cannot increafe. This is the reafon, as will be feen hereafter more fully, why the trade in exports as well as imports is confined within fuch narrow bounds.

The Britifh merchants in. Italy and other foreign countries, not being members of the company, (and to become free of the company they muft come to England, cannot trade with Britifh houfes in Turkey; and thefe, if they-will trade to Italy, muft trade with foreigners: thus all combinations of the trades are prevented. Englifh veflels in the Mediterranean might often make a voyage to Turkey, inftead of lying in an Italian port, and return time enough to take in their cargoes for England.

The great preference given to Britifh veffels in the Mediterranean would affure them an employnent whenever they want freights. This carrying or caravan trade is fo extenfive, 
that, befies the French, the little ftate of Ragufa has no lefs than 400 veffels in it.

Were the mafters of thips, their owners, and the Englifh merchants in Italy and Turkey, under no reftraint in regard to the Levant Company, people would rifk more readily the fending their veffels to the Medicerranean to get employment in this carrying bufinefs, and, their fpeculation in trade being free, they would find means to employ their veffels in the intervals of their being without freights; the mafters; owners, and correfpondents might combine their own fpeculations in merchandife with their carrying bufinefs, and thus keep them conftantly employed. It is the want of thefe refources to our fhips, that prevents Englin owners from fending their Aips into the Mediterranean to feek freights, and prevents the few which do go thither from profiting fo mueh by it as thofe of other nations, whofe houfes of trade are nearer, and whofe trade is under no reftrictions.

Had the Turkey trade in England never been a monopoly, the French would never have got poffeffion of almoft all the cloth trade; and the laying it open will be the only means of our coming in again for any confiderable thare in it. There is a greater demand in Turkey for the light Languedoc cloths, than for any other fort. The Furks clothe their fervants twice a year; and the French cloth, made into loofe garments; (which laft much longer than the tight European drefs, is ftrong enough for their purpofe, and its cheapnefs caufes it to be preferred; poorer people, who form the great body of confumers, bay it alfo for ceconomical reafons. Englith broad cloth, called mahoot, (of a light quality, made purpofely for the Turkey market,) is only worn by thofe in eafier circumftances. Confiderable quantities of cloth have alfo of late years come to Turkey from Germany.

It is the opinion of many people well acquainted with thefe matters, that the Englin manufacturers might make the fame fort of cloth as the Languedoc, and as cheap as the 
French; but, as long as the Levant Company exifts, who is to undertake it? Were the trade laid entirely open, it is probable that all kinds of Englifh manufacturers would fend people (called riders) to Turkey to feek for commiffions, as they do to all parts of Europe. This practice, though not very agreeable to Englifh merchants, (which however may not be the cafe in Turkey, as they may find the mediation of merchants neceffary, wrould greatly increafe the vent of Fnglifh commodities, and thefe induftrious people might poffibly be the means of our regaining the cloth trade.

The few merchants who are in the true fecret of the Levant trade, can employ in it their whole capital advantageoufly, and therefore do not feek for new branches, or how to recover old ones which are loft.-This is the great fecret.

The French do not get their wool cheaper than we do; the price of labour may be lefs; but will not fuperior fkill and induftry, with larger capitals, compenfate this fingle circumftance againft us? Experience in other articles hews it, as in the manufactures of Manchefter, Sheffield, and Birmingham.

It is very worthy of attention, that the French cannot make fo cheap as we can the fame kinds of cloth, which our people bring to the Turkey market; it is not that they cannot make them fo fine, for they make in France much finer cloth than that kind of broad cloth made in. England purpofely for the Turkey market. There is alfo a coarfe ftrong cloth brought to Turkey from England, called londras: thefe the French cannot make fo cheap neither; nor are their shalloons fo cheap. In thort, there is no fort of woollen ftuff made in the two countries, of the fame quality, which the Englifh do not fell cheaper than the French. The fact feenas to be, that the French invented a kind of cloth more proper for the general confumption of Turkey than that which the Englifh had brought thither; and the Englifh neyer attempted to follow their example, but continued car- 
rying to the market a fort of cloth, which at laft got almof out of ufe. Whenever the Englith thall have made and brought to Turkey the fame kind of cloth as the French, and cannot afford it fo cheap, then with certainty we may conclude that the French have an advantage over us; but till then it ought to be doubted, and certainly it merits the trial; but a fair trial never can be made till the Levant trade is entirely free.

But even fuppofing that we cannot regain the cloth trade, there are very many other objects worth attending to, and which may be of great national advantage.

The Manchefter ftuffs would find a great vent in all parts of Turkey. The manufactories of Aleppo and Damafcus are almoft ruined; and if the Manchefter people were to imitate the Turkifl pattems of their ftufs, they could certainly afford them cheaper. Imitations of the Surat and Bengal goods of filk and cutton, which are enormouny dear, would find alfo a ready fale in Turkey; and cotton velvets, velverets, \&cc. Birmingham and Sheffield wares would be articles of importance. The Turks, both in Europe and Afia, have a great partiality for all thefe kinds of Englin manufactures, and in general the epithet Englim is fynonimous with excellent.

Thefe articles at prefent are not attended to; but the mafters of hips, who bring out their little ventures to Turkey in a contraband manner, in thefe kind of things, make great profits; they can, however, bring only fmall quantities, left the Levant Company thould take umbrage at it. A few of thefe goods alfo find their way to Turkey from Italy, but greatly enhanced in their price from the many hands they go through, and therefore this channel does not afford a great vent for them. Linen may likewife be an article of exportation for Turkey. The Turks wear linen of a hard twifted thread, very open and unbleached, which comes moftly from Egypt, and is exceedingly dear, but is the moft plcafant kind to wear in hot weather. No European nation 
has yet undertaken to imitate it; but it is probable it might be made in Ireland infinitely cheaper than in Egypt: if this was the cafe, it would be of great importance. The German linens begin to be fold in confiderable quantities in Turkey; but they never will fupply the place of the Egyptian, on account of their quality. Vaft quantities of the above mentioned articles come from Venice and Germany, where they are dearer, and of worfe quality, than thofe manufactured in England.

Were I to enter into an enumeration of all the Englith manufactures that could be fold in Turkey, and particularly in the interior parts of Afia, and point out the different ports to which they might be fent, the detail would be too long for a general reprefentation; but collectively it muft be very obvious to every perfon acquainted but generally with the trade of Turkey, that our exportations to tirat country muft become of great importance in a few years, were the monopoly removed, and the agents of the manufacturers fent to travel through the country, and get certain information of the ftate of its trade and manufactories.

Salt fifh, could the Newfoundland fhips, \&c. go directly to Turkey as they go to Italy, would be a very important branch.

The Eaft India Company could fupply the Turkey market with mullins much cheaper than they are brought by the way of Baffora, of Gidda, and Suez, which trade is entirely in the hands of their fervants: the trial has been fuccefsfully made; but the members of the Levant Company have other articles enow in which to inveft their whole capitals. Other nations now bring large quantities of munins to Turkey. Britifh muflins (i.e. manufactured in Britain) alfo fell to confiderable profit.

Let all this be mere fuppofition, is not the object of importance enongh to give it a fair trial? and does not common fenfe fay, that a trade freed from obftacles muft flourifh more than when clogged with the moft unfupportable thackles, or 
with any thackles at all ? May it not be alked, what juft right have the members of the Levant Company to lay reftraints on this trade by their bye-laws? I have heard this fubject difcuffed in Turkey, where people certainly underftand the trade of the country better than in England, and $I$ never heard one plaufible reafon alleged in favour of the company. Sophiftical arguments may be produced in London, which may appear plaufible to thofe who are not informed of the real ftate of matters in Turkey.

To fhow what little efforts have been made by the company to extend the trade, and how little they deviate from the-footiteps of their forefathers, I will cite two ftriking infances:

Mr. John Humphrys, of Conftantinople, was the firf, who, a few years ago, imagined that Englifh fhalloons might be fold in Conftantinople, and they foon became a very important article for exportation to Turkey. The French have not been able to make them fo cheap.

Mr. Peter Took, of Conftantinople, only about twenty years ago, difcovered that he might buy raw filk from the frit hands at Brufa, (the hills behind this city are vifible from our merchants houfes in Pera,) and thus make his returns direct to England. Before that period, from the firft exiftence of the company, the merchants of Conftantinople had always fent their money to Smyrna to be invelted in filk, which the Turks and Jews of Smyrna bought at Brufa.

There is a great demand in Turkey for Staffordmire earthen-ware, which would become a very important article of commerce.

Perhaps the greateft importation of Britifh articles into Turkey would be by foreigners, or natives of the Turkin provinces, as is the cafe in many branches of our commerce, where fuch reftraints on foreigners do not exilt; for inftance, every one knows that not one-tenth part of our exports to Ruflia are on account of the Ruffia Company in London, or of the Britifh Factory in Ruflia. Thefe articles are fent to 
Ruffia for account of foreigners fettled in Ruffia, or Ruffians, and fome part for account of our manufacturers. With refpect to Germany this is ftill more the cafe.

The Levant Company exact a duty on all merchandife exported to and imported from Turkey, befides a confulage in the ports of Turkey on all the exports and imports in Britifh veffels. This confulage is a very heavy burthen on our trade, and particularly, when it is confidered that fome other nations pay none. The following are the words of the company's bye-law :

"A At a general court, \&c. the following orders were eftablifhed as proper and expedient for the fupport of the company's affairs, and for the government of the trade; and they were confirmed at a general court held $3^{\mathrm{d}}$ of March I775.

"It was refolved and ordered, That all goods exported from Turkey or Egypt for Great Britain thall pay three confulages and one-half, or feven in the hundred, according to the rates of the company's tarif, in fuch fpecies of the grand feignior's coin as his officers receive for cuftoms; which confulage fhall be paid, one-half in thirty days, and the other half in fixty days after the departure of the hip, \&c.; and the company's treafurers are not to take any notes or obligations for the payments of confulages, but they are to infift upon being paid in money when it is due.

" That all goods imported, \&c. into Great Britain, fhall pay one impofition according to the company's rates, \&x. except cotton and emery ftones, \&c.

"That all goods imported into Turkey or Egypt, from Leghorn, or any other port or ports of Chriftendom, by Britifh fubjects or Britifh thips, for account of foreigners, thall pay a confulage of two in the hundred; \&x.

"That all goods exported from Conftantinople, Smyrna, and Aleppo, to Leghorn, or any other foreign port or ports of Chriftendom, by Britilh fubjects; on foreign fhips, on acVot. III. 
count of Britifh fubjèts, thall pay a confulage of one in the hundred, \&c.

"That all goods imported into Turkey or Egypt, by ftrangers, upon Britifh thips, from any foreign port, \&c. fhall pay two in the hundred, \&c. and in like manner exported, two in the hundred, \&c." and feveral other regulations for the paying of confulage, of leffer importance, which I omit for brevity.

"April 29th, I785. It is refolved and ordered, \&c.

"That all goods, excepting raw fllk, mohair yarn, and drugs, exported from Turkey and Egypt, in the time of the plague, to Malta, Ancona, Venice, Meffina, Leghorn, Genoa, or Marfeilles, for the purpofe of performing quarantine, and which are to be re-fhipped on the fame fhip for Great Britain or Ireland, thall pay a confulage of two in the hundred only."

Befides this revenue, the company have for many years received an affiftance from government of five thoufand pounds a year. All thefe fums are expended for paying a part of the falary of the ambaffadors at Conftantinople, the confuls at the feveral ports in Turkey, the chancellors and drogomans (or interpreters), and for defraying the expences attending vifits from the ambaffador to the porte, and of the confuls to pafhas, befides extraordinary prefents made at the firft audience of a new ambaffador and of a conful; for paying avanias (or money extorted by falfe accufations), and public entries of confuls, which were formerly very coftly; and finally, for the expences of the company and its officers at home.

Were our trade put on the fame footing as the Ruffian, the five thoufand pounds government now pays, would perhaps more than fuffice for all the expences which then would be neceffary; and that our trade could be put on the fame footing, I fuppofe nobody will deny. The Ruffian trade to Turkey is free to every one; there is no tax on it, either under 
under the appellation of confulfhip or otherwife; no fee is taken at any ambaffador's, conful's, or chancellor's office, for documents neceffary for the difpatch of trade; no prefents are made by confuls to pafhas or other officers; no avania is fubmitted to.

A conful at Smyrna only is neceffary. Vice-confuls in the other ports would anfwer every purpofe for the protection of trade; and there would be found merchants enow, who would be glad of the office without pay, for the honour of it, which in Turkey is confiderable. There is at this day no neceffity for confuls living in fuch great ftate as they did a few years ago. The foreign minifters at Conftantinople have very confiderably retrenched their expences.

The power of an ambaffador and of a conful in Turkey is very great; it extends even to life and death. By one of the articles of the eapitulations (or treaty with the porte) it is ftipulated, that in all criminal cafes wherein fubjects of the porte are not concerned, ambaffadors or confuls thall punifh the criminal according to the laws of their country. In the Dutch capitulations this is expreffed fill ftronger. As crimes committed in a ftate are crimes immediately againft that ftate, the cognizance of them belongs to it alone. The fultan delegates his power to the ambaffadors and confuls; and if in punifhing the criminal they exceed the rule prefcribed by the laws of their own country, they are only anfwerable for their conduct to the fultan; but the fultan takes no cognizance of it, therefore they are without control, and their power is defpotic. It is indeed true, that they generally fend fuch offenders home to their country; there hąve, however, with other nations, been examples where an European has killed a fubject of the porte, and juftice being demanded the ambaffador or conful has put the criminal to death. Should it happen that an Englifhman killed a Turk, it would certainly be better that the ambaffador or conful thould caufe him to be hanged by his own people, than that he fhould deliver him up to the Turks, for júftice being demanded, 
there is no other alternative; if he efcaped, the confequence might be a general mafracre; we have lately had an example at Smyrna exactly of this nature, which coft the lives of many hundreds, and caufed the European quarter to be reduced to afhes. There is no poffibility of fending the criminal home if the populace demand juftice.

The company have given alfo another power to the ambafladors and confuls over merchants, which free traders may not approve of. Their bye-law is : "If any factor or factors fhall have any dealings with any perfon battulated by the lord ambaffador, or the conful of any of the fcales (ports, Scala Italian) in Turkey, with the advice of the refpective factories, fuch factor or factors thall pay a fine for every of fence to the amount of three confulages upon the value of the tranfaction by or with fuch battulated perfon, without appeal, \&c." Battulation with them fignifies interdiction of all commerce with the perfon battulated. The intention was to prevent the factors or merchants having dealings with litigious perfons of the country; but this power has been abufed.

The ambaffador formerly had a confiderable revenue from protections granted to fubjects of the porte, under the title of Baratli, or honorary drogomans; but thefe protections having been totally difregarded by the prefent fultan, who without any ceremony has beheaded feveral perfons poffeffed of them, both that income and that fource of conftant litigation with the porte are partly done away. It were to be withed that this privilege was wholly abolithed. The French feveral times propofed giving it up, and at a time when it. was refpected, and lucrative to their ambaffadors.

The French alfo, on the reprefentation of their ambaffador, M. de St. Priefte, laid the Levant trade open; the confequence was, that immenfe quantities of French goods were carried to Tukey by fubjeets of the porte; but the company at Marfeilles found means to get their exclufive privilege renewed; they had fuffered, but the country had gained. At 
prefent every one has liberty to trade; and fince our fleet has left the Mediterranean, their commerce is revived, and, except the trade to Great Britain be equally free when a peace takes place, we fhall have little chance of being able to rival them: but we muft not wait till that period arrives to lay our trade open; it muft be done immediately.

As all communication with the Levant by fea is cut off, there remains no refource to our merchants, but to carry on their trade through Ruffia; and though this be a circuitous way, it is not by far fo expenfive as might be imagined. The freights to the Baltic are very low, as half the fhips go out empty. The carriage from Riga to Cherfon, or Niccolai on the Bog, is moftly by water, and the land carriage in Ruffia is not one fourth of the price it is in Germany. The expence on cloth would be trifing, and on cheap and bulky goods er en would not be equal to the enormous price of infurance paid for armed thips, which run the voyage at prefent, and which is not equal to the rifk; it is indeed fo great, that government thould, perhaps, interfere. At Cherfon there are good veffels to be found, which in three days may carry the goods to Conftantinople at a reafonable freight.

But in order to open fuch a communication, liberty muft be obtained of the emperor of Ruffia to fend merchandize in tranfto (without paying duty) acrofs Ruffia; and there is no doubt but that fovereign, who has ftudied Adam Smith's book on the Wealth of Nations, and who is perfectly acquainted with the principles of commerce and navigation, would fee the very great advantage which would accrue to Ruffia by fuch a trade, both on account of the fums which would remain in the country for expences of carriage, the employment of a number of people, and alfo the encouragement it would be to the Ruffian navigation in the Black Sea; but he never would grant fuch a privilege to a part of the Britifh nation exclufively, and fhut out from it the Ruffia merchants, who carry on a branch of commerce fo advan- 
tageous to his empire, nor exclude his own fubjects from it. Before this can be done, the Turkey Company mult be abolifhed.

At prefent a few goods, I am informed, have been fent to Hamburgh, thence to Vienna, and down the Danube, where they are thipped for Conftantinople. The freight to Hamburgh is dearer than it is to Riga; the charges acrofs Germany ten times as much as acrofs Ruffia. At the mouth of the Danube there are only bad Turkifh or Greek veffels to be freighted, on which no regular infurance can be made. At Cherfon there are fome hundreds of veffels, among which many equal thofe to be found in the ports of other feas, and a reafonable infurance may be made on them by fafe underwriters; but the route through Germany does not neceffitate an abolition of the Levant Company.

VIII. Obfervations on Naples Yellow, and the different $M_{e-}$ thods of preparing it. By Profeffor BecKM ANN.

NAPLES yellow, which is alfo called Neapolitan earth, in Italian Giallolino, and in French Jaune de Naples, has the appearance of an earth, is of a pale orange-yellow colour, ponderous, granulated, exceedingly friable, does not efflorefce, nor become moift when expofed to the air, but when applied to the tongue feems to adhere to it. When reduced to a fine powder, it remains for fome time fufpended in water, but foon depofits itfelf at the bottom in the form of a fime. When boiled with water, the water, at leaft fometimes, is obferved to have a fomewhat faline tafte. It does not effervefee with acids, but is in part diffolved by aquaregia (nitro-muriatic acid). In the fire it emits no fulphureats vapour, is difficult to be fufed, and by that operation undergoes no material change, only that its colour becomes fomewhat redder. When fufed with colourlefs glafs, it gives it a 